\title{
ALLELOPATHIC INFLUENCES OF ARTEMISIA DUBIA WALL. EX. BESSER ON SEED GERMINATION AND SEEDLING VIGOR OF PARTHENIUM HYSTEROPHORUS L.
}

\section{Manisha Sharma and Anjana Devkota}

Journal of Institute of Science and Technology

Volume 22, Issue 2, January 2018

ISSN: 2469-9062 (print), 2467-9240 (e)

Editors:

Prof. Dr. Kumar Sapkota

Prof. Dr. Armila Rajbhandari

Assoc. Prof. Dr. Gopi Chandra Kaphle Mrs. Reshma Tuladhar

JIST, 22 (2): 117-128 (2018)

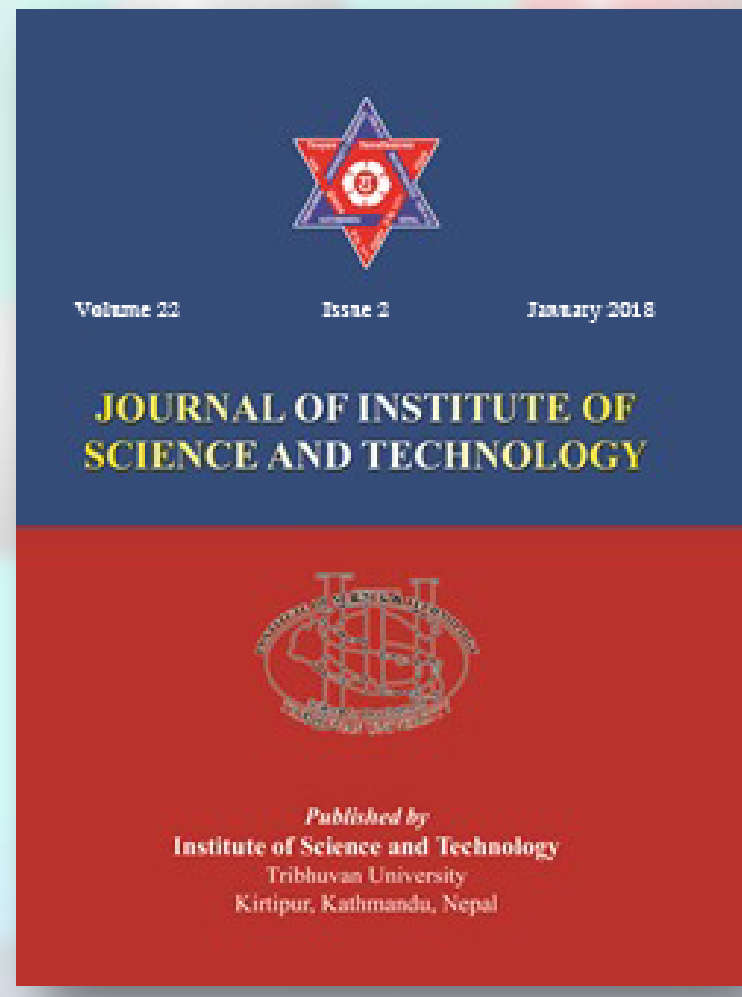

Published by:

Institute of Science and Technology

Tribhuvan University

Kirtipur, Kathmandu, Nepal 


\title{
ALLELOPATHIC INFLUENCES OF ARTEMISIA DUBIA WALL. EX. BESSER ON SEED GERMINATION AND SEEDLING VIGOR OF PARTHENIUM HYSTEROPHORUS L.
}

\author{
Manisha Sharma and Anjana Devkota* \\ Central Department of Botany, Tribhuvan University \\ *Corresponding E-mail: devkotaa@gmail.com
}

Received: 30 December, 2016; Revised: 19 June, 2017; Accepted: 27 July, 2017

\begin{abstract}
Allelopathic effect of aqueous (leachate) and solvent extract (hexane, chloroform, methanol and water) of leaf, stem and root of donor plant Artemisia dubia was studied on germination and seedling vigour of Parthenium hysterophorus. Extraction and quantification of different parts in different solvent was done by percolation method. Bioassay was performed by allowing $P$. hysterophorus seed to germinate in Petri dishes (for solvent, aqueous) in laboratory condition against varied concentrations of prepared extracts of A. dubia. All the tested extract (aqueous, solvent) from different plant parts significantly checked the germination of $P$. hysterophorus in higher concentration with the effect being more pronounced from the leaf of $A$. dubia. Linear growth of root and shoot of $P$. hysterophorus was also checked significantly with increasing concentration of tested plant extract. The order of allelopathic influence was leaf $>$ stem $>$ root in all the cases and it was concentration dependent. Length of root was retarded while stem length experienced no effect, sometime elongation (stem and root extract of leachate, stem extract of hexane and chloroform). These results provide ample evidence that allelopathic potential exist in A. dubia and this can be exploited for the control of P.hysterophorus.
\end{abstract}

Keywords: Allelopathic influences, Artemisia dubia, Parthenium hysterophorus, Percolation method, Linear growth.

\section{INTRODUCTION}

Parthenium hysterophorus L. (Common name: ragweed) locally called "Kanike ghas" is a new invasive and exotic weed species reported to be rapidly spreading in Nepal. Parthenium weed (Parthenium hysterophorus L.), regarded as one of the top seven world's worst weeds (Patel, 2011) is known for its serious human health risks (McFadyen, 1995; Shrestha, 2016). Intensive studies and documentation of its impacts on health, crops or biodiversity is still lacking in Nepal. Inventory and assessment of invasive species of Nepal done by The World Conservation Union (IUCN) has ranked $P$. hysterophorus to be of moderate threat in terms of invasiveness. However, this does not mean it is of less importance. In the light of global acceptance of its noxious character and exhaustive invasive potential recognized, it is necessary to control before it creeps to wreak havoc.
Weed control is heavily dependent on the synthetic chemical formulations (herbicides) and this has been the basis for high input commercial agriculture ensuring high production. However, its impact on human health and environment, evolving herbicideresistant ecotypes and cross-resistance in weeds has persuaded scientists to look for environment friendly, safe and sustainable alternatives. This has urged the shift in direction from weed control to weed management rather than the conventional weed removal that exclusively rely on the synthetic herbicides. Allelochemicals may give way to discovery of new herbicides which are environmentally benign. Thus knowledge about the allelochemical behavior of the plant is important for the environment friendly weed management. The science of allelopathy has received a great concern for researches, and allelopathic aspects of many weeds are being investigated considerably, however work in this sector is very scant in Nepal where wide ranges of allelopathic plants exist. 
Artemisia dubia Wall. Ex. Besser is a next problematic weed in Nepal found from eastern to western zone, at the altitudinal range of 1200-3400 $\mathrm{m}$ (Press et al., 2000). It grows vigorously and highly competitive, thus making pure stand of Artemisia often seen in open places. Artemisia produces different flavonoids, phenolics, terpenoids and wide array of secondary products with a higher concentration in aerial portions. These allelochemicals influence other ecosystem components that in turn drive interaction which determine the structure of plant community. Use of easily available and viable local resource that is traditionally practiced by farmer, in a form of botanical pesticides for pest control measures is still finding importance. Therefore, allelopathy being popular area of science is utilized for pest control. Present research was conducted to screen phytotoxic potentiality of. A. dubia against $P$. hysterophorus as a source of natural product solution to weed management.

\section{MATERIALS AND METHODS}

\section{Collection of plant material}

Plant samples of A. dubia and P. hysterophorus were collected from Kathmandu valley (Latitude/Longitude-27 41 ' $\mathrm{N} / 85^{\circ} 19^{\prime} \mathrm{E}$ ) which lies at $1300 \mathrm{~m}$ altitude and falls on sub-tropical climatic zone. The collected samples were identified by experts of Central Department of Botany Tribhuvan University, Kirtipur. Herbaria of samples were deposited in TUCH, Kirtipur. Plant parts (stem, root and leaves) of A. dubia were collected randomly from Kalanki, Kathmandu. They were immediately cleaned and chopped into small pieces and shade dried. Dried materials were grounded in blender separately and packed in polythene bags and stored for further utilization.

The noxious weed $P$. hysterophorus seeds (test seeds) were collected from Kirtipur area where it maintained monoculture stand in July, hand threshed and then stored in airtight bottle in dark at room temperature.

\section{Extraction of plant materials}

Percolation method (Trusheva et al., 2007) was followed for extraction of plant materials in different solvent in ecology laboratory of Central Department of Botany. For this, $50 \mathrm{gm}$ of plant (Artemisia dubia) powder (leaf, stem and root) was kept in $500 \mathrm{ml}$ conical flask with $300 \mathrm{ml}$ solvent (hexane, methanol, chloroform and water) separately and left for 15 days. Thereafter the extract was filtered. Filtrate was concentrated with the help of rotatory evaporator under reduced pressure. The above process was repeated for all plant parts (leaf, stem and root) extracted in different solvent viz. hexane, chloroform, methanol and water. The crude extracts were weighed and measured yield followed by storage at $4^{\circ} \mathrm{C}$ in air tight bottles until further use (Mahida \& Mohan, 2007).

Laboratory test of Allelopathy (Germination and early seedling growth bioassays)

\section{Bioassay with aqueous leachate extract}

Ten grams of fresh plant materials (leaf, stem and roots) were collected randomly in vegetative stage in a sunny mid day of July and immersed in $100 \mathrm{ml}$ of distilled water in beaker separately and kept at room temperature for $24 \mathrm{~h}$ and filtered using muslin cloth. This filtrate was taken as stock solution with $10 \%$ of concentration and different concentration i.e. $2 \%, 4 \%, 6 \%, 8 \%$ and $10 \%$ solution were made by dilution with distilled water and used for Petri bioassay against test seeds.

Test seeds were imbibed in distilled water for $36 \mathrm{~h}$. The Petri dishes were sterilized with ethyl alcohol. The test seeds of Parthenium hysterophorus for germination were placed in Petri dishes lined with single layer of filter paper supported by sterile absorbent cotton and moistened by $5 \mathrm{ml}$ of different concentration of prepared test solution. Control set received distilled water. Each treatment was replicated thrice having 30 seeds in each Petri dish. Petri dishes were kept in laboratory condition in room temperature and finally seed germination and root and shoot elongation were measured in twelfth day of sowing (Ismail \& Chong 2002).

\section{Bioassay with solvent extract}

Ten mg of different solvent extracts (hexane, methanol, chloroform and water) of different parts (leaf, stem and root) of the plant were re-dissolved in $1 \mathrm{ml}$ of dimethyl sulphoxide (DMSO) in sterile vials and completely dissolved by continuous shaking. This solution was then transferred to reagent bottle containing $99 \mathrm{ml}$ of distilled water to make concentration of $1000 \mathrm{ppm}$ and it was used as stock solution. Different concentrations (1000 ppm, $100 \mathrm{ppm}, 10 \mathrm{ppm}$ and $1 \mathrm{ppm}$ ) of solvent extracts were made by diluting stock solution with distilled water. Then viable seeds (imbibed for $36 \mathrm{~h}$ ) of $P$. hysterophorus were allowed to germinate in sterilized Petri dishes lined with filter paper supported with absorbent cotton and moistened in the different concentration of the extract. For control, 1\% of DMSO solution was used. Each treatment was replicated thrice with 30 seeds in 
each Petri dishes. After twelfth days, the germination percentage, and linear growth of root and shoot of seedling were measured.

\section{RESULTS}

\section{Yield of A. dubia}

Yield of A. dubia varied for different solvents. It was highest in highly polar solvent (water) and was lowest in non-polar solvent (hexane). Extract was highest from the leaf part compared to stem and root (Figure 1).

Allelopathic effect of Artemisia dubia on Parthenium hysterophorus

Effect of aqueous leachate extract

Allelopathic effect was different for different parts at different concentration. Germination inhibition showed a varied pattern. Stem extract even at lower concentration resulted in high inhibition. Similarly, root extract showed greater inhibition at medium concentration $(4 \%)$ but it's concentration of $6 \%$ resulted in abrupt increase in germination. However general pattern for all the parts extract was inhibition in highest concentration (Figure 2).

Leaf leachate extract resulted in high retardation of root length compared to shoot length. Stem extract promoted the shoot length and it was maximum for higher concentrations, on the other hand root length was inhibited compared to control but it was independent of concentration. All concentrations of root leachate extract resulted in elongation of shoot length, but effect on root length was less significant (Table 1).

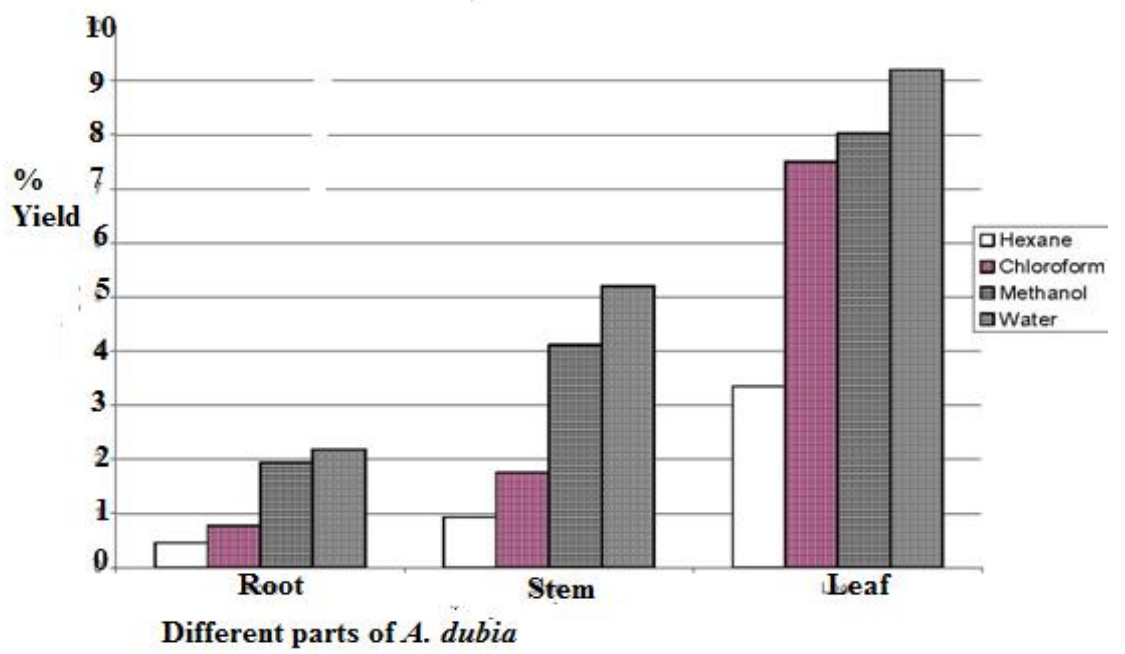

Fig. 1. Yield Percentage of crude extract of different parts of Artemisia dubia with different solvent.

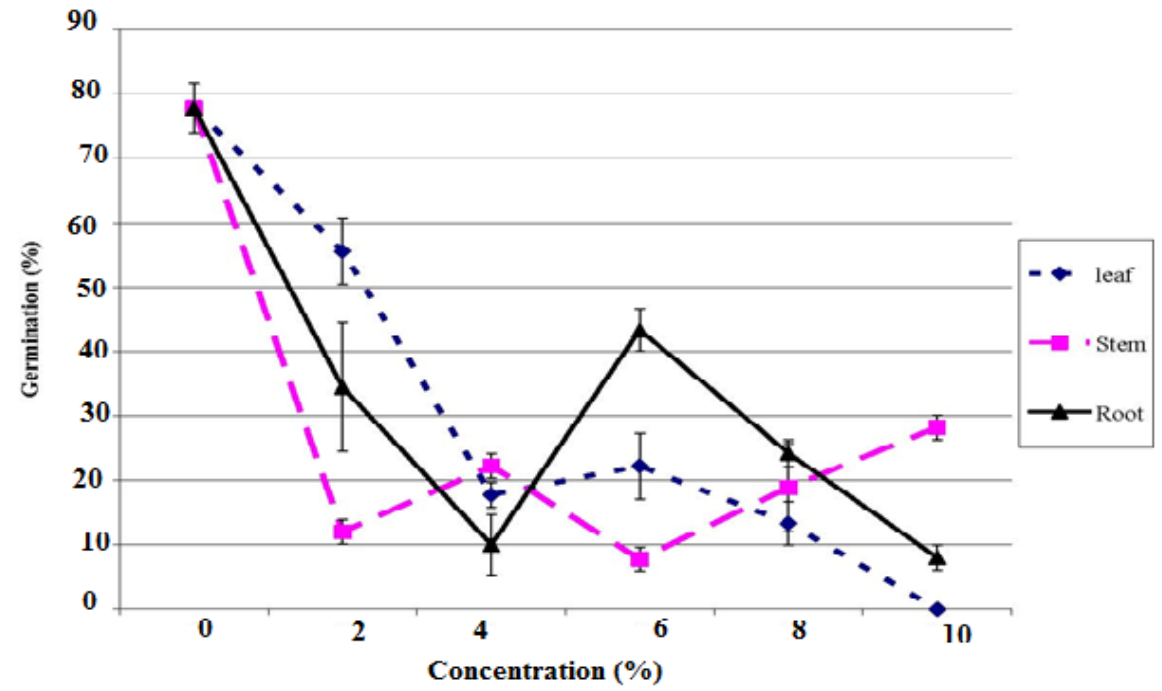

Fig.2. Mean germination of Parthenium hysterophorus treated with various concentration of aqueous leachate extract of leaf, stem and root of Artemisia dubia (Number of test seeds $=30$; Bar indicate \pm S.D.) 
Table 1: Mean values of root and shoot length of Parthenium hysterophorus seedling at different concentration of leachate extracts (Each value is the mean of samples; significance difference is shown by different letters at $\alpha=0.05$ )

\begin{tabular}{|c|c|c|c|}
\hline \multirow[t]{2}{*}{ Parts used } & \multirow[t]{2}{*}{ Concentration } & \multicolumn{2}{|c|}{ Parthenium seedling } \\
\hline & & Shoot Length $(\mathrm{cm}) \pm$ S.D & Root Length $(\mathrm{cm}) \pm$ S.D. \\
\hline \multirow{8}{*}{ Leaf } & Control & $1.53 \pm 0.31 \mathrm{c}$ & $3.65 \pm 0.63 \mathrm{c}$ \\
\hline & 2 & $1.33 \pm 0.25 \mathrm{~b}$ & $3.07 \pm 0.46 \mathrm{~b}$ \\
\hline & 4 & $1.03 \pm 0.36 \mathrm{a}$ & $1.45 \pm 0.37 \mathrm{a}$ \\
\hline & 6 & $1.24 \pm 0.27 \mathrm{~b}$ & $1.56 \pm 0.33 \mathrm{a}$ \\
\hline & 8 & $1.3 \pm 0.24 *$ & $1.56 \pm 0.25 *$ \\
\hline & 10 & - & - \\
\hline & F-Value & 28.45 & 32.12 \\
\hline & $\mathrm{P}$-value & 0.000 & 0.000 \\
\hline \multirow{8}{*}{ Stem } & Control & $1.53 \pm 0.31 \mathrm{a}$ & $3.65 \pm 0.63 b$ \\
\hline & 2 & $1.37 \pm 0.19 \mathrm{a}$ & $2.25 \pm 0.51 \mathrm{a}$ \\
\hline & 4 & $1.81 \pm 0.30 \mathrm{~b}$ & $2.41 \pm 0.61 \mathrm{a}$ \\
\hline & 6 & $1.52 \pm 0.44 *$ & $2.06 \pm 0.43 *$ \\
\hline & 8 & $2.03 \pm 0.27 \mathrm{c}$ & $2.14 \pm 0.60 \mathrm{a}$ \\
\hline & 10 & $2.19 \pm 0.34 \mathrm{c}$ & $2.13 \pm 0.61 \mathrm{a}$ \\
\hline & F-Value & 38.90 & 21.35 \\
\hline & P-value & 0.000 & 0.000 \\
\hline \multirow{8}{*}{ Root } & Control & $1.53 \pm 0.31 \mathrm{a}$ & $3.65 \pm 0.63 \mathrm{~b}$ \\
\hline & 2 & $1.45 \pm 0.39 \mathrm{a}$ & $2.73 \pm 0.60 \mathrm{a}$ \\
\hline & 4 & $1.95 \pm 0.28 *$ & $2.48 \pm 0.46 *$ \\
\hline & 6 & $1.78 \pm 0.30 \mathrm{~b}$ & $2.42 \pm 0.47 \mathrm{a}$ \\
\hline & 8 & $2.06 \pm 0.52 \mathrm{c}$ & $2.55 \pm 0.51 \mathrm{a}$ \\
\hline & 10 & $1.44 \pm 0.19 *$ & $1.98 \pm 0.36 *$ \\
\hline & F-Value & 38.45 & 23.67 \\
\hline & P-value & 0.000 & 0.000 \\
\hline
\end{tabular}

Note: - = No germination; $*$ = Excluded from statistical analysis (small sample size)

\section{Effect of solvent extracts}

\section{Effect of hexane extract}

Germination was inhibited by hexane fraction of all parts extract at highest concentration (1000 ppm). Inhibition at lower concentration was promoted by leaf and root extract. Stem extract exhibited slight inhibition initially, but subsequently at medium concentrations resulted in promotion of germination (Figure 3 ).
The hexane extract of all parts significantly reduced root elongation with effect of leaf extract being highly significant compared to stem and root. Leaf extract resulted in inhibitory effect in shoot elongation at higher concentration but stem extract had growth promotion effect. There were homogenous variances of root extract treatment in shoot length of ragweed compared to control (Table 2). 


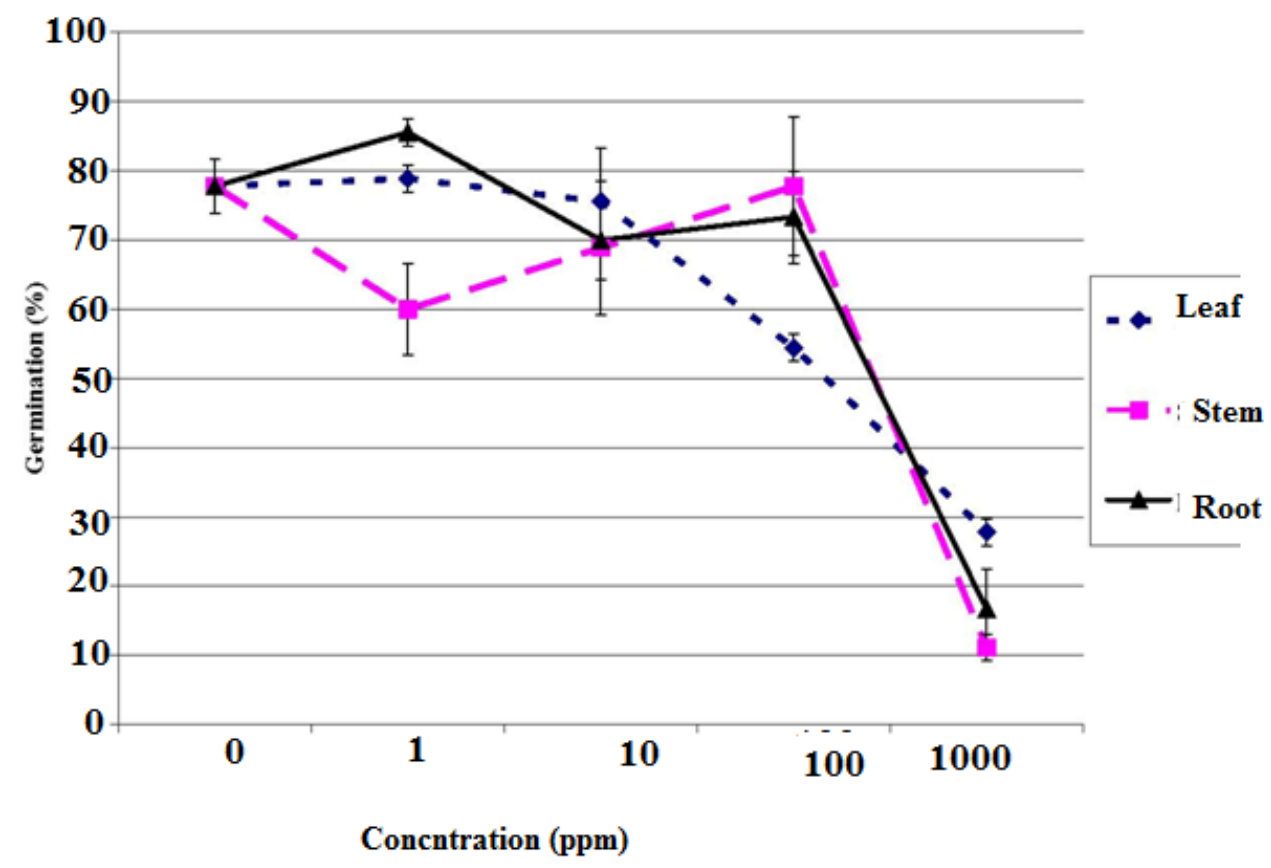

Fig. 3. Mean germination of Parthenium hysterophorus treated with various concentration of hexane extracts of leaf, stem and root of Artemisia dubia (Number of test seeds $=30$; Bar indicate \pm S.D.)

There was significant difference $(\mathrm{p}=0.000)$ in mean values of root due to root length extract however only stem extract treatment produced significant difference in shoot length (Table 2).

Table 2: Mean values of root and shoot length of Parthenium hysterophorus germinated at different concentration of hexane extracts (Each value is the mean of samples; significance difference is shown by different letters at $\alpha=0.05$ )

\begin{tabular}{|c|c|c|c|}
\hline \multirow{2}{*}{$\begin{array}{c}\text { Parts of Extract } \\
\text { used }\end{array}$} & \multirow{2}{*}{$\begin{array}{c}\text { Treatment (Concentration } \\
\text { in ppm) }\end{array}$} & \multicolumn{2}{|c|}{ Parthenium seedling } \\
\hline & & Shoot Length $(\mathrm{cm}) \pm$ S.D & Root Length $(\mathrm{cm}) \pm$ S.D. \\
\hline \multirow{7}{*}{ Leaf } & Control & $1.14 \pm 0.1 \mathrm{a}$ & $3.61 \pm 0.6 \mathrm{~d}$ \\
\hline & 1 & $1.10 \pm 0.20 \mathrm{a}$ & $3.48 \pm 0.81 \mathrm{~d}$ \\
\hline & 10 & $1.19 \pm 0.20 \mathrm{ab}$ & $3.15 \pm 0.60 \mathrm{c}$ \\
\hline & 100 & $1.28 \pm 0.35 \mathrm{~b}$ & $2.15 \pm 0.42 \mathrm{~b}$ \\
\hline & 1000 & $1.16 \pm 0.23 \mathrm{a}$ & $1.85 \pm 0.38 \mathrm{a}$ \\
\hline & F-Value & 3.88 & 62.06 \\
\hline & P-value & 0.004 & 0.000 \\
\hline \multirow{7}{*}{ Stem } & Control & $1.14 \pm 0.1 \mathrm{ab}$ & $3.61 \pm 0.6 \mathrm{~d}$ \\
\hline & 1 & $1.09 \pm 0.19 \mathrm{a}$ & $3.44 \pm 0.71 \mathrm{~d}$ \\
\hline & 10 & $1.26 \pm 0.32 \mathrm{bc}$ & $3.03 \pm 0.54 \mathrm{c}$ \\
\hline & 100 & $1.41 \pm 0.31 \mathrm{~d}$ & $2.32 \pm 0.43 \mathrm{~b}$ \\
\hline & 1000 & $1.34 \pm 0.25 \mathrm{~cd}$ & $1.96 \pm 0.25 \mathrm{a}$ \\
\hline & F-Value & 14.17 & 57.05 \\
\hline & $\mathrm{P}$-value & 0.000 & 0.000 \\
\hline
\end{tabular}




\begin{tabular}{|l|l|l|l|}
\hline \multirow{4}{*}{ Root } & Control & $1.14 \pm 0.1 \mathrm{a}$ & $3.61 \pm 0.6 \mathrm{c}$ \\
\cline { 2 - 4 } & 1 & $1.15 \pm 0.22 \mathrm{a}$ & $3.41 \pm .06 \mathrm{c}$ \\
\cline { 2 - 4 } & 10 & $1.20 \pm 0.20 \mathrm{a}$ & $3.12 \pm 0.5 \mathrm{~b}$ \\
\cline { 2 - 4 } & 100 & $1.23 \pm 0.22 \mathrm{a}$ & $2.65 \pm 0.6 \mathrm{a}$ \\
\cline { 2 - 4 } & 1000 & $1.22 \pm 0.27 \mathrm{a}$ & $2.68 \pm 0.61 \mathrm{a}$ \\
\cline { 2 - 4 } & F-Value & 1.8 & 22.65 \\
\cline { 2 - 4 } & P-value & 0.129 & 0.000 \\
\hline
\end{tabular}

\section{Effect of chloroform extract}

Treatment with chloroform extract resulted in inhibition in germination. Inhibition increased with increased concentration for all the parts extract (Figure 4). Inhibitory effect on root length was significant with heterogeneity in variance for treatment with all parts extract. However, homogeneity in variance was observed in shoot length when treated with root and leaf extract. Stem extract on the other hand had significant growth promotion effect in shoot length (Table 3). There was no significant difference in mean values of shoot length when treated with root and leaf extract but, shoot extract treatment resulted in significant difference. On the other hand effect of all parts extracts produced significant effect on root length (Table 3).

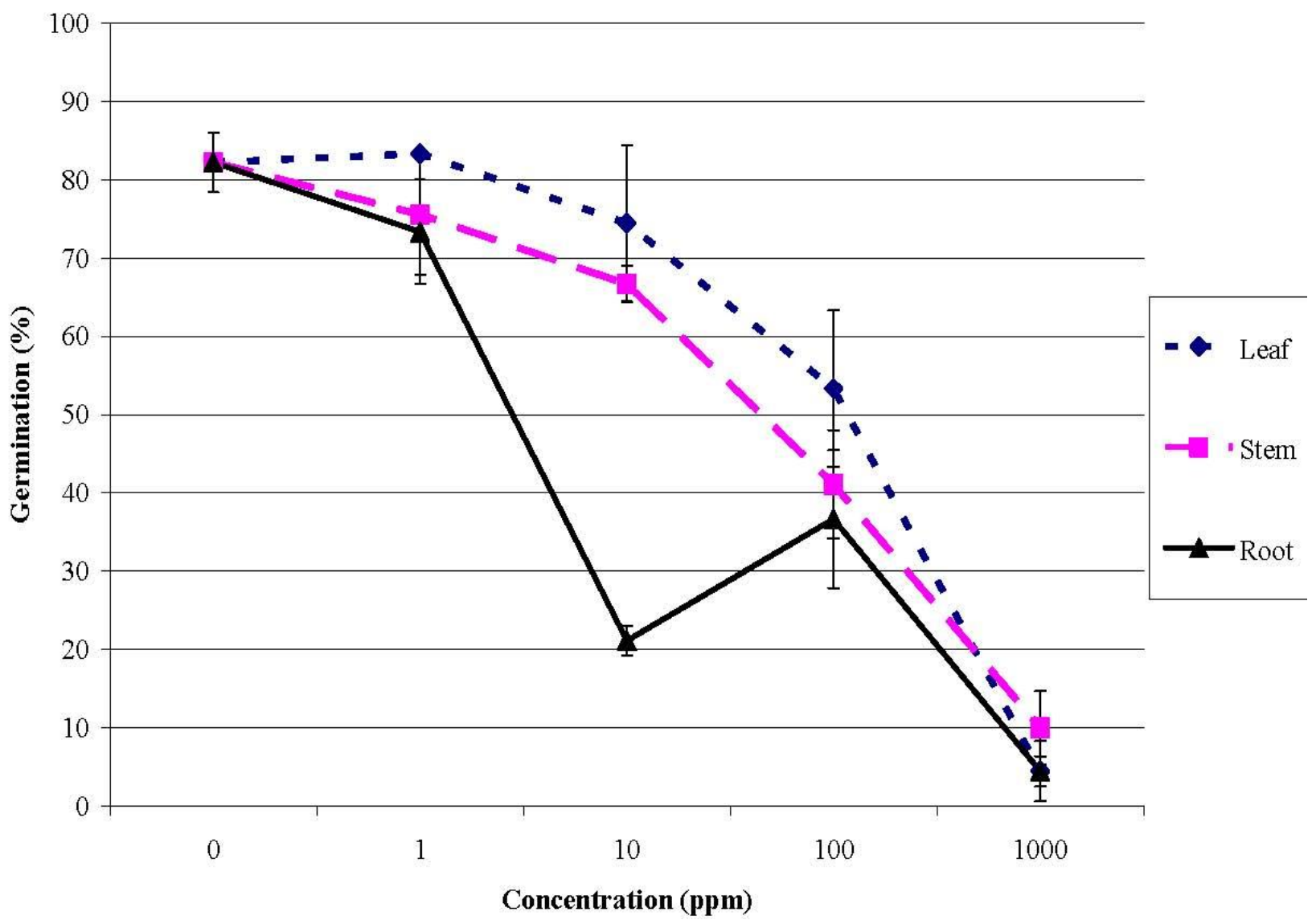

Fig. 4. Mean germination of Parthenium hysterophorus treated with various concentration of chloroform extract of leaf, stem and root of Artemisia dubia (Number of test seeds = 30;

Bar indicate \pm S.D.) 
Table 3: Mean values of root and shoot length of Parthenium hysterophorus weed germinated at different concentration of chloroform extracts (Each value is the mean of samples; significance difference is shown by different letters at $\alpha=0.05$ )

\begin{tabular}{|c|c|c|c|}
\hline \multirow{2}{*}{$\begin{array}{c}\text { Parts of Extract } \\
\text { used }\end{array}$} & \multirow{2}{*}{$\begin{array}{c}\text { Treatment (Concentration } \\
\text { in ppm) }\end{array}$} & \multicolumn{2}{|c|}{ Parthenium seedling } \\
\hline & & Shoot Length $(\mathrm{cm}) \pm$ S.D & Root Length $(\mathrm{cm}) \pm$ S.D. \\
\hline \multirow[t]{7}{*}{ Leaf } & Control & $1.10 \pm 0.21 \mathrm{a}$ & $3.69 \pm 0.64 \mathrm{~d}$ \\
\hline & 1 & $1.16 \pm 0.24 \mathrm{ab}$ & $3.47 \pm 0.66 \mathrm{c}$ \\
\hline & 10 & $1.21 \pm 0.23 \mathrm{~b}$ & $2.64 \pm 0.57 \mathrm{~b}$ \\
\hline & 100 & $1.12 \pm 0.25 \mathrm{~b}$ & $2.06 \pm 0.56 \mathrm{a}$ \\
\hline & 1000 & $0.53 \pm 0.05 *$ & $1.2 \pm 0.1 *$ \\
\hline & F-Value & 2.53 & 86.97 \\
\hline & P-value & 0.057 & 0.000 \\
\hline \multirow[t]{7}{*}{ Stem } & Control & $1.10 \pm 0.21 \mathrm{a}$ & $3.69 \pm 0.64 \mathrm{~d}$ \\
\hline & 1 & $1.18 \pm 0.31 \mathrm{a}$ & $3.40 \pm 0.65 \mathrm{c}$ \\
\hline & 10 & $1.37 \pm 0.33 \mathrm{~b}$ & $2.90 \pm 0.53 \mathrm{~b}$ \\
\hline & 100 & $1.66 \pm 0.36 b$ & $2.55 \pm 0.61 \mathrm{a}$ \\
\hline & 1000 & $1.5 \pm 0.2 *$ & $2.16 \pm 0.26 *$ \\
\hline & F-Value & 30.04 & 33.72 \\
\hline & P-value & 0.000 & 0.000 \\
\hline \multirow[t]{7}{*}{ Root } & Control & $1.10 \pm 0.21 \mathrm{a}$ & $3.69 \pm 0.64 \mathrm{c}$ \\
\hline & 1 & $1.13 \pm 0.26 \mathrm{a}$ & $3.56 \pm 0.64 \mathrm{c}$ \\
\hline & 10 & $1.3 \pm 0.27 \mathrm{~b}$ & $2.99 \pm 0.62 \mathrm{~b}$ \\
\hline & 100 & $1.16 \pm 0.3 \mathrm{a}$ & $2.53 \pm 0.67 \mathrm{a}$ \\
\hline & 1000 & $0.7 \pm 0.20 *$ & $1.6 \pm 0.11 *$ \\
\hline & F-Value & 5.04 & 32.09 \\
\hline & P-value & .002 & 0.000 \\
\hline
\end{tabular}

Note: $*$ = Excluded from statistical analysis (small sample size)

\section{Effect of methanol extract}

Germination was inhibited by the methanol fraction of A. dubia extract from all parts compared to control. After initial inhibition at concentration of 1 ppm, both root and stem extract resulted in slight promotion at medium concentration. Leaf extract resulted in significant inhibition of germination compared to stem and root extract (Figure 5). 


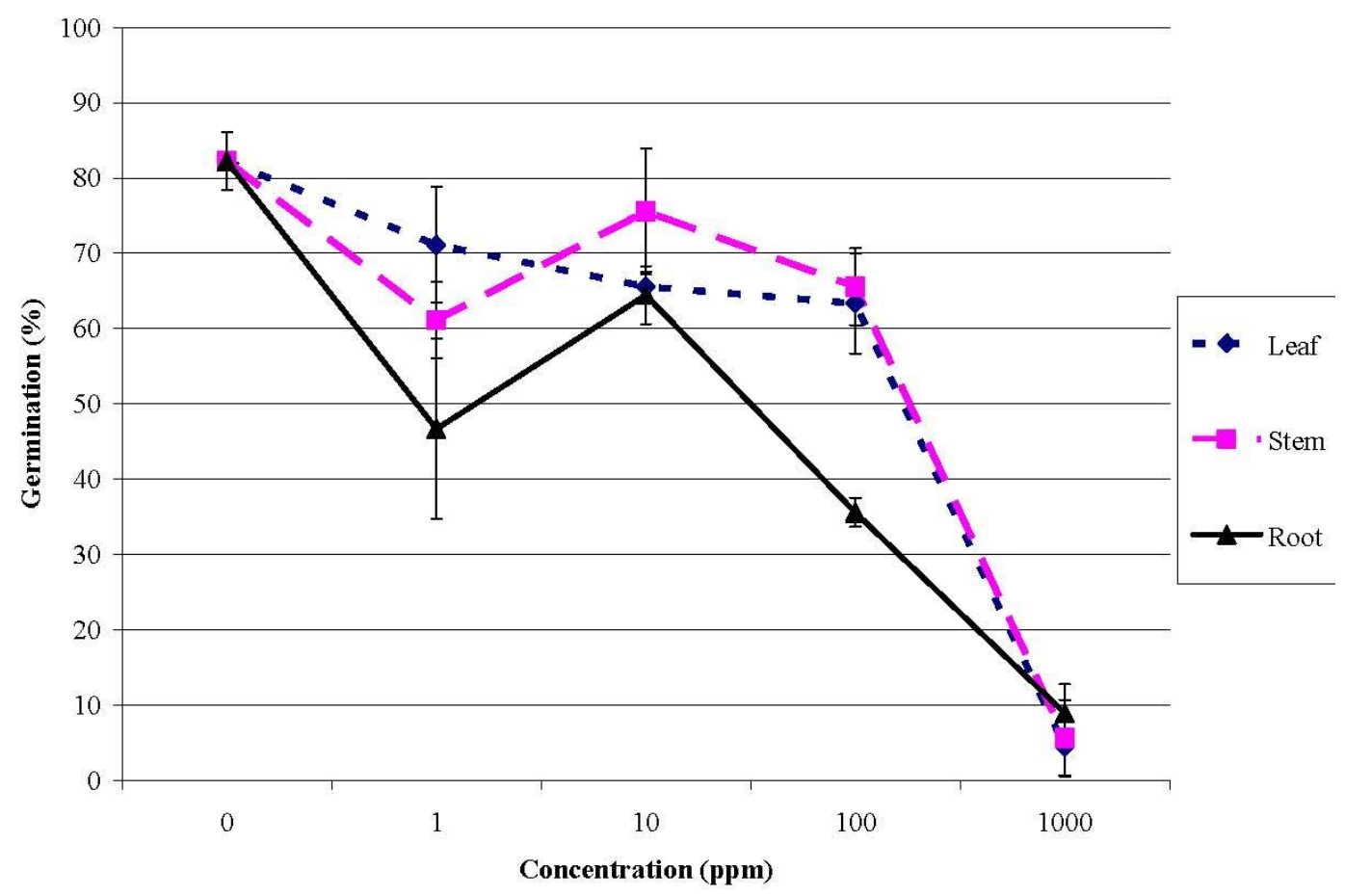

Fig. 5. Mean germination of Parthenium hysterophorus treated with various concentration of methanol extract of leaf, stem and root of Artemisia dubia (Number of test seeds $=30$; Bar indicate \pm S.D.)

There was significance difference $(p=0.000)$ in root length among different concentration of treatment of plant extract. Effect was significantly high in higher concentration in all plant parts. Homogeneity in variance was observed in shoot length in treatment with leaf and root extract but shoot extract showed significant elongation compared to control (Table 4). ANOVA test showed that root length of seedling was significantly affected by treatment with all the parts. However, effect on shoot was not pronounced except in treatment with shoot extract (Table 4).

Table 4: Mean values of root and shoot length of Parthenium hysterophorus germinated at different concentration of methanol extracts (Each value is the mean of samples; significance difference is shown by different letters at $\alpha=05$

\begin{tabular}{|l|l|l|l|}
\hline $\begin{array}{c}\text { Parts of Extract } \\
\text { used }\end{array}$ & \multicolumn{1}{|c|}{$\begin{array}{c}\text { Treatment } \\
\text { Concentration in ppm) }\end{array}$} & \multicolumn{2}{c|}{ Parthenium seedling } \\
\hline & & Shoot Length(cm) \pm S.D & Root Length(cm) \pm S.D. \\
\hline \multirow{5}{*}{ Leaf } & Control & $1.10 \pm 0.21 \mathrm{a}$ & $3.69 \pm 0.64 \mathrm{c}$ \\
\cline { 2 - 4 } & 1 & $1.12 \pm 0.21 \mathrm{ab}$ & $3.10 \pm 0.64 \mathrm{~b}$ \\
\cline { 2 - 4 } & 10 & $1.20 \pm 0.23 \mathrm{~b}$ & $2.50 \pm 0.68 \mathrm{a}$ \\
\cline { 2 - 4 } & 100 & $1.05 \pm 0.27 \mathrm{a}$ & $2.32 \pm 0.48 \mathrm{a}$ \\
\cline { 2 - 4 } & 1000 & $0.65 \pm 0.23 *$ & $1.3 \pm 0.14 *$ \\
\cline { 2 - 4 } & F-Value & 4.44 & 64.34 \\
\cline { 2 - 4 } & P-value & .005 & 0.000 \\
\hline \multirow{4}{*}{ Stem } & Control & $1.10 \pm 0.21 \mathrm{a}$ & $3.69 \pm 0.64 \mathrm{c}$ \\
\cline { 2 - 4 } & 1 & $1.23 \pm 0.32 \mathrm{~b}$ & $2.62 \pm 0.66 \mathrm{a}$ \\
\cline { 2 - 4 } & 10 & $1.31 \pm 0.30 \mathrm{~b}$ & $\mathrm{~b}$ \\
\hline
\end{tabular}




\begin{tabular}{|l|l|l|l|}
\hline \multirow{4}{*}{} & 100 & $1.31 \pm 0.34 \mathrm{~b}$ & $2.44 \pm 0.57 \mathrm{a}$ \\
\cline { 2 - 4 } & 1000 & $1.1 \pm 0.39 *$ & $1.66 \pm 0.54 *$ \\
\cline { 2 - 4 } & F-Value & 7.44 & 49.46 \\
\cline { 2 - 4 } & P-value & .000 & .000 \\
\hline \multirow{4}{*}{ Root Control } & $1.10 \pm 0.21 \mathrm{a}$ & $3.69 \pm 0.64 \mathrm{c}$ \\
\cline { 2 - 4 } & 1 & $1.10 \pm 0.28 \mathrm{a}$ & $3.13 \pm 0.57 \mathrm{~b}$ \\
\cline { 2 - 4 } & 10 & $1.09 \pm 0.28 \mathrm{a}$ & $2.56 \pm 0.59 \mathrm{a}$ \\
\cline { 2 - 4 } & 100 & $0.99 \pm 0.29 \mathrm{a}$ & $2.38 \pm 0.55 \mathrm{a}$ \\
\cline { 2 - 4 } & 1000 & $0.7 \pm 0.23 *$ & $1.48 \pm 0.29 *$ \\
\cline { 2 - 4 } & F-Value & 1.41 & 52.3 \\
\cline { 2 - 4 } & P-value & 0.239 & 0.000 \\
\hline
\end{tabular}

Note: $*$ Excluded from statistical analysis (small sample size)

\section{Effect of water extract}

Germination was highly inhibited by all parts of water extract of Artemisia dubia. The effect increased with increasing concentration and leaf extract resulted in maximum inhibition compared to stem and root (Figure 6).

Aqueous fraction of all parts showed strong inhibitory effect on root length elongation with heterogeneity in variance when compared among treatments with different concentrations. Stem extract resulted in slight elongation in shoot length at lower concentration (10 ppm); root fraction treatment showed no difference in shoot length compared to control in all concentration except higher concentration which led to retardation in shoot length. Significant retardation in shoot length was observed for both stem and leaf extract at higher concentration though it was not pronounced at lower concentration (Table 5).

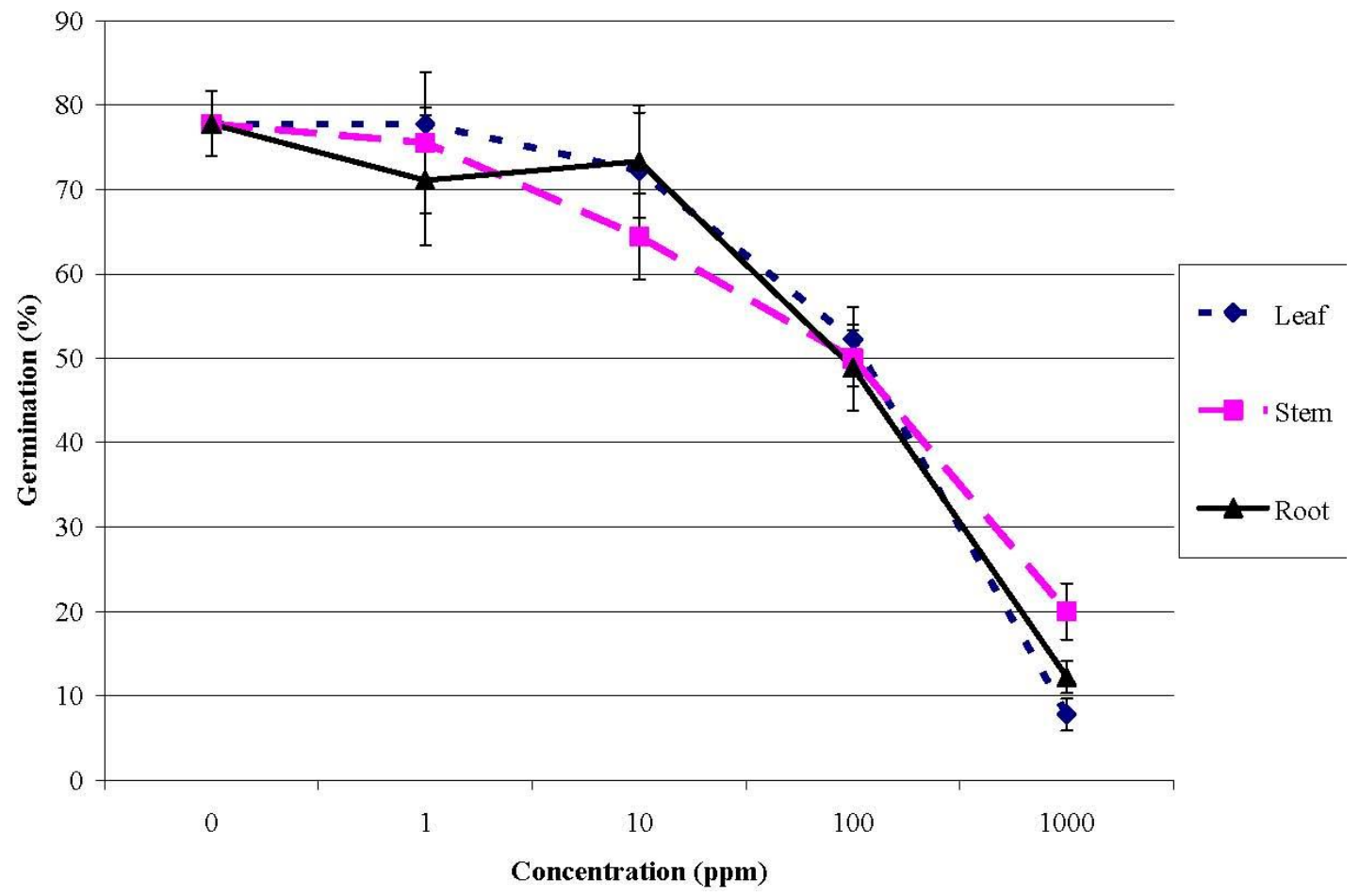

Fig.6. Mean germination of Parthenium hysterophorus treated with various concentration of water extract of leaf, stem and root of Artemisia dubia (Number of test seeds = 30; Bar indicate \pm S.D.) 
Table 5: Mean values of root and shoot length of Parthenium hysterophorus seedling at different concentration of water extracts (Each value is the mean of samples; significance difference is shown by different letters at $\alpha=0.05)$.

\begin{tabular}{|c|c|c|c|}
\hline \multirow{2}{*}{$\begin{array}{c}\text { Parts of Extract } \\
\text { used }\end{array}$} & \multirow{2}{*}{$\begin{array}{c}\text { Treatment } \\
\text { (Concentration in ppm) } \\
\end{array}$} & \multicolumn{2}{|c|}{ Parthenium seedling } \\
\hline & & Shoot Length $(\mathrm{cm}) \pm$ S.D & Root Length $(\mathrm{cm}) \pm$ S.D. \\
\hline \multirow{7}{*}{ Leaf } & Control & $1.14 \pm 0.20 \mathrm{ab}$ & $3.61 \pm 0.68 \mathrm{~d}$ \\
\hline & 1 & $1.09 \pm 0.21 \mathrm{a}$ & $3.29 \pm 0.57 \mathrm{c}$ \\
\hline & 10 & $1.19 \pm 0.27 \mathrm{~b}$ & $2.74 \pm 0.71 \mathrm{~b}$ \\
\hline & 100 & $1.08 \pm 0.26 \mathrm{a}$ & $2.49 \pm 0.48 \mathrm{a}$ \\
\hline & 1000 & $0.67 \pm 0.22 *$ & $1.27 \pm 0.34 *$ \\
\hline & F-Value & 2.45 & 34.62 \\
\hline & P-value & .064 & .000 \\
\hline \multirow{7}{*}{ Stem } & Control & $1.14 \pm 0.20 \mathrm{ab}$ & $3.61 \pm 0.68 \mathrm{~d}$ \\
\hline & 1 & $1.13 \pm 0.20 \mathrm{ab}$ & $3.55 \pm 0.63 \mathrm{~d}$ \\
\hline & 10 & $1.27 \pm 0.37 \mathrm{c}$ & $3.17 \pm 0.72 \mathrm{c}$ \\
\hline & 100 & $1.18 \pm 0.29 \mathrm{c}$ & $2.65 \pm 0.92 \mathrm{~b}$ \\
\hline & 1000 & $1.02 \pm 0.17 \mathrm{a}$ & $1.46 \pm 0.31 \mathrm{a}$ \\
\hline & F-Value & 4.25 & 42.73 \\
\hline & P-value & 0.002 & 0.000 \\
\hline \multirow{7}{*}{ Root } & Control & $1.14 \pm 0.20 \mathrm{~b}$ & $3.61 \pm 0.68 \mathrm{~d}$ \\
\hline & 1 & $1.16 \pm 0.21 \mathrm{~b}$ & $3.48 \pm 0.57 \mathrm{~d}$ \\
\hline & 10 & $1.12 \pm 0.20 \mathrm{~b}$ & $3.18 \pm 0.63 \mathrm{c}$ \\
\hline & 100 & $1.11 \pm 0.24 \mathrm{~b}$ & $2.51 \pm 0.57 \mathrm{~b}$ \\
\hline & 1000 & $0.77 \pm 0.31 \mathrm{a}$ & $1.45 \pm 0.45 \mathrm{a}$ \\
\hline & F-Value & 7.79 & 46.14 \\
\hline & $\mathrm{P}$-value & 0.000 & 0.000 \\
\hline
\end{tabular}

Note: $*=$ Excluded from statistical analysis (small sample size)

\section{DISCUSSION}

\section{Yield of Artemisia dubia}

The yield of dried powder extract was highest in highly polar solvent (water) and was lowest in nonpolar solvent (hexane). Extract was highest for the leaf part compared to stem and root. This is due to drawing of soluble pigments in extract. The fact besides the high amount of extraction with water solvent may be due to the presence of water-soluble polar compounds present in plant according to the principle "like dissolves like". This result is in coherence with the earlier findings reported by Poudel (2004) for Artemisia dubia and Suwal (2006) for Chromolaena odorata.
Allelopathic effect of Artemisia dubia on Parthenium hysterophorus

Effect on the germination

There was significant inhibitory effect on germination of Parthenium seed by different solvent extract. Aqueous leachate was pronounced at higher concentration but the extract at lower concentration at some instances even promoted germination. This may be due to requirement of higher concentration to cause the death of the embryo. Similar finding was reported by Escudero et al. (2000) when they tested seed germination of Helianthemum squamatum and Lactuca sativa against varied concentration of aqueous extract of 
Artemisia herba-alba. Inhibition was higher for leaf extract compared to stem and root extract and this may be because of repository inhibitory compounds present in leaf. This result is comparable to earlier findings that reported more harmful effect of leaf extract than shoot and root extract (Poudel 2004; Suwal 2006).

\section{Effect on seedling growth}

The allelopathic influences of extracts of different parts of A. dubia on Parthenium hysterophorus seedling vigor (shoot/root length) varied and was dependent on concentration and type of solvents (hexane, chloroform, methanol, water) used for extraction. All parts extract (solvent/leachate) resulted in the retardation of root length but inhibition of shoot length elongation was observed only in few instances. This strong effect on root in comparison to shoot may be due to root's direct contact with extract, which is comparable to earlier findings reported by Bhowmik and Doll (1984) and Rice (1984). The tested four organic solvent (hexane, chloroform, methanol and water) extract had attributed significant and similar effects on germination and seedling vigor of Parthenium hysterophorus. This is against the earlier findings of Malla (2003) on Ageratum conyzoids. This could be because allelopathic interference of allelochemicals is selective in nature.

In aqueous leachate extract, both root and shoot leachate led to elongation of ragweed seedling stem. This could be because, allelopathic compounds leached out completely from the dust of prepared plant parts. While in aqueous leachate extract, live tissue (without maceration) were immersed in water so chemicals that got leached from the unexposed cells were in the concentrated level that has promoted growth. Lovett (1989) has reported that biological activities of receiver plants to allelochemicals are concentration dependent with a response threshold. Responses are characteristically, stimulation at low concentrations of allelochemicals but inhibition as the concentration increases.

Effect had followed the order of leaf $>$ stem $>$ root, where solvent extracts of all parts resulted in root retardation but stem extract except in aqueous fraction has resulted in growth promotion effect on shoot length elongation. Similar concentration dependent and differential effect was reported by Mo et al (2005) from aqueous extract of Lactarius hatsudake on rice which was stimulation on shoot growth but inhibition on root growth.

Poudel (2004) has reported the presence of saponins and tanins in aqueous fraction of A. dubia. Saponins are natural group of compounds known for its wide range of allelopathic activity (Olezek et al. 1992; Waller et al. 1995) and as a promising source that could be used as herbicides (Sondhia \& Saxena 2003). Tanins are complex molecules, which reduce the digestibility of plant tissue by herbivores; however there are several hydrolysable tannins that are known to be growth and germination inhibitor (Harborne 1984). Lydon et al. (1997) has suggested that other molecules may also be involved in the phytotoxic effect as they found aqueous extract devoid of artemisinin to be equally phytotoxic as compared to treatment with artemisin. Besides, flavonoids and phenolics (known group of allelochemicals) are also reported from some of Artemisia spp (Suleimenov et al. 2005; Modallal \& Al-Charchafchi 2006). These suggest A. dubia to be repository of both polar and non polar allelochemicals that could be exploited for the control of ragweed and further provide conformity to its herbicidal potentiality.

\section{CONCLUSION}

The crude extract of A. dubia has been found according to the type of plant part used and type of solvent used in extraction. The yield obtained was in the following trend; leaf $>$ stem $>$ root and water $>$ methanol $>$ chloroform $>$ hexane. All of the solvent extract of $A$. dubia resulted in similar effect on germination and seedling growth of Parthenium hysterophorus. Omitting some exceptions in lower concentrations, all treatments (aqueous leachate / solvent extract) was found inhibitory, being more pronounced in accordance with the increasing concentration. Among all the extracts, leaf extract has been found to impose more inhibitory effect. Root length of seedling was retarded in almost all cases while such regular pattern in growth was not seen in stem length.

\section{ACKNOWLEDGEMENT}

We are indebted to Prof. Dr. Pramod Kumar Jha for the discussion during the preparation of manuscript and the laboratory facilities at Central Department of Botany.

\section{REFERENCES}

Bhowmik, P. C. and Doll, J. D. (1984). Allelopathic effects of annual weed residues on growth and nutrient uptake of corn and soybeans. Agronomy Jounal, 60: 185-188. 
Escudero, A.; Albert, M. J.; Pita, J. M. and Garcia, F. P. (2000). Inhibitory effect of Artemisia herba-alba on germination of gypsophyte Helianthemum squamatum. Plant Ecology, 148: $71-80$.

Harborne, J. B. (1984). Phytochemical Methods. Chapman and Hall, London.

Ismail, B. S. and Chong, T. V. (2002). Effects of aqueous extracts and decomposition of Mikania micrantha H. B. K. debris on selected agronomic crops. Weed Biology Management, 2: 31-38.

Lovett, J. V. (1989). In: Phytochemical Ecology: Allelochemicals, Mycotoxins and Insect Pheromones and Allomones. Edited by $\mathrm{C}$. $\mathrm{H}$. Chou and G. R. Waller. Taipei, ROC, pp 4967.

Lydon, J.; Teasdale, J. R. and Chem, P. K. (1997). Allelopathic activity of annual warmwood, (Artemisia annua) and the role of artemisinin. Weed science, 45: 807-811.

Mahida, Y. and Mohan, J. S. S. (2007). Screening of plants for their potential antibacterial activity against Staphylococcus and Salmonella spp. Natural Product Radiance, 6(4): 301-305.

Malla, B. (2003). Allelopathic potential of Ageratum spp.. M. Sc. dissertation, Central Department of Botany, Tribhuvan University, Kirtipur, Kathmandu, Nepal.

McFadyen, B. E. (1995). Parthenium weed and human health in Queensland. Australian Family Physician, 24: 1455-1459.

Mo, M.; Xiao, Q.; Zhang, X. and Nie, C. (2005). Allelopathy of aqueous extracts of Lactarius hatsudake on several crops and barnyardgrass (Echinochloa crusgalli L.). In: Establishing the Scientific Base. Proceedings of the 4th World Congress on Allelopathy, eds J. Harper, M. An, H. Wu and J. Kent, Charles Sturt University, Wagga Wagga, NSW, Australia. International Allelopathy Society.http://www.regional.org.au/au/allelo pathy/2005/.

Modallal, N. M. and Al-Charchafchi, F. M. R. (2006). Allelopathic effect of Artemisia harba- alba on germination and seedling growth of Anabasis setifera. Pakistan Journal of Biological Sciences, 9(9): 17951798.

Olezek, W.; Lurjysta, M. and Gorski, P. M. (1992). Alfafa saponin, the allelopathic agents in allelopathy. In: Allelopathy, Basic and Applied Aspects, (eds.) S.J.H. Rizvi and V. Rizvi. Chapman and Hall, New York. pp 151-162.

Patel, S. (2011). Harmful and beneficial aspects of Parthenium hysterophorus: an update, 3 Biotechnology, 1(1): 1-9.

Poudel, P. (2004). Phytochemical screening and allelopathic effect of Artemisia dubia Wall. Ex. Besser on seedling of Rice and Barnyard grass. M. Sc. dissertation, Central Department of Botany, Tribhuvan Universiy, Kirtipur, Kathmandu, Nepal.

Press, J. R.; Shrestha, K. K. and Sutton, D. A. (2000). Annotated Checklist of the Flowering Plants of Nepal. The Natural History Museum, London and Central Department of Botany, Tribhuvan University, Kathmandu.

Rice, E. L. (1984). Allelopathy. $2^{\text {nd }}$ edition, Academic Press Inc., Orlando, Florida, USA.

Shrestha, B. B. (2016). Invasive Alien Plant Species in Nepal. P. K. Jha, M. Siwakoti and S. Rajbhandary (Eds.) Frontiers of Botany. Central Department of Botany, Tribhuvan University, Kirtipur, Kathmandu. pp. 269.

Sondhia, S. and Saxena, N. K. (2003). Allelopathic effect of Xanthium strumarium L. on some weeds. Geobios, 30(2-3): 173-176.

Suwal, M. M. (2006). Allelopathic Effects of Chromolaena odorata (L.) King and Robinson on seedling growth of Paddy and Barnyard grass. M. Sc. dissertation., Central Department of Botany, Tribhuvan University, Kirtipur, Kathmandu, Nepal.

Suleimenov, E. M.; Smagulova, F.M.; Morozova, O. V.; Raldugin, V. A.; Bagryanskaya, I. Y.; Galilov, Y. V. et al. (2005). Sesquiterpene lactones and Flavonoids form Artemisia albida. Chemistry of Natural Compounds, 41: 689-691.

Trusheva, B.; Trunkova, D. and Bankova, V. (2007). Different extraction methods of biologically active components from propolis: a preliminary study. Chemistry Central J., 7: 1-13.

Waller, G. R.; Yang, C. F.; Chen, L. F.; Su, C. H.; Liou, R. M.; Wu, S. C. et al. (1995). Can soyasaponin $\mathrm{I}$ and mono bidesmosides isolated from mungbean serve as growth enhance in mungbean and lettuce? Medicine and Biology, 405: 123-139. 